\title{
Article \\ Polyphasic Characterization of Acidovorax citrulli Strains Originating from Serbia
}

\author{
Nevena Zlatković ${ }^{1, *}$, Katarina Gašić ${ }^{1}\left(\mathbb{D}\right.$, Nemanja Kuzmanović $^{2}$, Anđelka Prokić ${ }^{3} \mathbb{D D}$, Milan Ivanović $^{3}$, \\ Svetlana Živković ${ }^{1}$ and Aleksa Obradović ${ }^{3}$ (D) \\ 1 Institute for Plant Protection and Environment (IPPE), Teodora Drajzera 9, 11040 Belgrade, Serbia; \\ gasickatarina@yahoo.com (K.G.); zivkovicsvetla@gmail.com (S.Ž.) \\ 2 Julius Kühn Institute, Federal Research Centre for Cultivated Plants, Institute for Plant Protection in \\ Horticulture and Forests, Messeweg 11/12, 38104 Braunschweig, Germany; kuzmanovic1306@gmail.com \\ 3 Faculty of Agriculture, University of Belgrade, Nemanjina 6, 11080 Belgrade, Serbia; \\ andjelka03@gmail.com (A.P.); milanivanovic007@yahoo.com (M.I.); aleksao@agrif.bg.ac.rs (A.O.) \\ * Correspondence: nevena_blagojevic@yahoo.com
}

Citation: Zlatković, N.; Gašić, K.; Kuzmanović, N.; Prokić, A.; Ivanović, M.; Živković, S.; Obradović, A. Polyphasic Characterization of Acidovorax citrulli Strains Originating from Serbia. Agronomy 2022, 12, 235 https://doi.org/10.3390/

agronomy12020235

Academic Editors

Agata Motyka-Pomagruk,

Monika Kałużna and Agnieszka

Emilia Misztak

Received: 31 October 2021

Accepted: 20 December 2021

Published: 18 January 2022

Publisher's Note: MDPI stays neutral with regard to jurisdictional claims in published maps and institutional affiliations.

Copyright: (C) 2022 by the authors. Licensee MDPI, Basel, Switzerland. This article is an open access article distributed under the terms and conditions of the Creative Commons Attribution (CC BY) license (https:// creativecommons.org/licenses/by/ $4.0 /)$.

\begin{abstract}
Acidovorax citrulli, the causal agent of bacterial fruit blotch (BFB), is an economically important pathogen of watermelon and related plant species worldwide. In the period 2014-2018, several outbreaks of BFB were observed in major watermelon production regions in Serbia. A total of 43 strains, isolated from symptomatic watermelon tissue, were analyzed by biochemical, pathogenic and molecular tests. Based on the phenotypic characteristics, PCR assay, and 16S rRNA gene sequence analysis, all strains were identified as A. citrulli. A multilocus sequence analysis of the four housekeeping ( $a d k, g y r B$, pilT and gltA) and three virulence genes (Aave_1548,avrRx01 and luxR) revealed that studied $A$. citrulli strains represent the homogeneous population and they clustered together with group II reference strain AAC00-1. Strain affiliation to group II was confirmed by PCR based on the putative type III secretion effector gene and by duplex PCR test. High homogeneity of studied strains was also confirmed by BOX-PCR. Differences were observed for two strains in their pathogenicity as well as susceptibility to copper compounds. Moreover, six major watermelon varieties grown in Serbia showed high sensitivity to the pathogen, while cross inoculation assay revealed that the strains were able to infect other species within the Cucurbitaceae family.
\end{abstract}

Keywords: bacterial fruit blotch; Acidovorax citrulli; watermelon; identification; MLSA

\section{Introduction}

Cucurbit cultivation contributes significantly to vegetable production in Serbia. Cucumber, watermelon, melon, pumpkin and muskmelon represent some of the most important species used for fresh consumption, but also for processing and the pharmaceutical industry. According to FAO statistics, Serbia belongs to a group of mid-range producing countries in Europe. In 2019, watermelon yield reached approximately 28.6 t/ha [1].

However, profitability of the production is often compromised by occurrence and spread of pathogenic microorganisms. Cucurbitaceous plants are especially susceptible to some bacterial diseases. An unknown disease first reported as seedling blight of watermelon occurred in 1965, in an agricultural station in Georgia, USA [2]. Initial symptoms were described as water-soaked spots of the lower surface of the cotyledons. The causal agent was identified as a new phytobacterium, Pseudomonas pseudoalcaligenes subsp. citrulli [3,4]. In 2008, this organism was reclassified as Acidovorax citrulli, the causal agent of bacterial fruit blotch (BFB) [5]. Until 1996, A. citrulli was largely studied as a pathogen of watermelon. However, in the next few years disease symptoms were noticed on other cucurbits. Rapidly, the pathogen has spread to many countries mainly via contaminated seed [6,7]. It caused considerable damage to the watermelon and melon industry in China and United States [8]. In Europe, the bacterium was first detected in Turkey, afterwards in Hungary and Greece [9-11]. Destructive disease outbreaks in the fields of other cucurbit 
species showed a wide host range within the family [12,13]. Assouline et al. [14] stated that the pathogen was detected in several shipments of tomato seeds imported from India, as well as in eggplant seedlings grown from imported seed [15]. This was the first detection of BFB pathogen outside the family Cucurbitaceae. A group of authors from Israel confirmed previous reports by isolating A. citrulli strains from symptomatic eggplants and tomato [16]. Likewise, Malliarakis et al. [17] reported the disease occurrence on tomato seedlings in Greece. As a consequence, serious losses in the production were recorded.

In Serbia, watermelon and melon production mostly originates from imported reproductive material, which created the risk of introduction of $A$. citrulli. The pathogen is listed on the national list of quarantine organisms, and was not recorded until 2014 [18]. Since then, several outbreaks of BFB on watermelon plants have been recorded countrywide.

According to previous research based on carbon substrate utilization, molecular methods, fatty acid methyl ester analysis (FAME) and repertoire of type III secretion effectors, A citrulli strains could be divided into two biochemically and genetically distinct groups, I and II [8,12,15,19-21]. Group I includes strains mainly recovered from melon and non-watermelon cucurbits, while group II comprises of strains mostly isolated from watermelon. However, the population of A. citrulli from Serbia was never studied in this manner and consequently there was no information regarding the genetic diversity and population structure of this new emerging pathogen. During intensive BFB investigation, starting from 1999, many results were consistent with the host preference statement [8,20,22]. Although these data proposed the host preference of groups I and II, greenhouse inoculation assay showed there is no clear evidence for rigid host specificity [12]. Similar results were reported by Zivanovic and Walcott [19]. Zhao et al. [21] indicated that there were possible variations in host preferences between I and II group strains in conditions of both natural infection and artificial inoculation. Their study showed that groups I and II diverge in the ability to infect foliage of different species within cucurbits and that host preference is more expressed in cucurbit fruit tissues.

In order to clarify the phylogenetic relationship of bacterial species within a genus, multilocus sequence analysis (MLSA) of housekeeping genes was used as a powerful tool [23]. According to MLSA A. citrulli strains clustered into two genetically distinct groups, corresponding to the previously described pulse field gel electrophoresis (PFGE) and multilocus sequence typing (MLST) analysis of housekeeping genes [8,24]. In addition, diversity within the strains isolated from different hosts was recorded based on repetitive element sequence-based PCR (rep-PCR) analysis [24].

This paper describes comprehensive characterization of this emerging pathogen isolated in Serbia based on biochemical, physiological and molecular tests, including phylogenetic analysis of the strains. Additionally, the host preference of A. citrulli strains was evaluated, as well as sensitivity of the strains to different bactericides.

\section{Materials and Methods}

\subsection{Sampling and Isolation of Bacterial Strains}

During August 2014, typical BFB symptoms were noted on mature watermelon (Citrullus lanatus) fruits originating from fields in the north of Serbia (Srem district). First symptoms were observed as water-soaked, irregularly shaped fruit lesions followed by rind cracks and inner tissue softening. Over the following years (2014-2018, except 2017), similar symptoms were detected in other watermelon growing localities. Pathogen isolation was carried out using fragments from border area between apparently healthy and diseased tissue, just beneath surface of the rind. The samples were macerated in $1 \mathrm{~mL}$ of sterile distilled water (SDW) and the macerate was streaked onto nutrient agar medium (NA, Torlak, Serbia), followed by incubation for $2-3$ days at $27^{\circ} \mathrm{C}$. Single colonies were purified and selected for identification and further characterization (Table 1). 
Table 1. Bacterial strains isolated in this study.

\begin{tabular}{|c|c|c|c|c|}
\hline \multicolumn{5}{|c|}{ Strain Data } \\
\hline Strain & Host (Variety) & Isolation Source & Locality & Year \\
\hline $\mathrm{KFB}^{\mathrm{a}} 340$ & C. lanatus, (Farao) & Fruit & Ašanja & 2014 \\
\hline KFB 341 & C. lanatus, (Farao) & Fruit & Ašanja & 2014 \\
\hline KFB 342 & C. lanatus, (Farao) & Fruit & Ašanja & 2014 \\
\hline KFB 343 & C. lanatus, (Farao) & Fruit & Ašanja & 2014 \\
\hline KFB 344 & C. lanatus, (Farao) & Fruit & Ašanja & 2014 \\
\hline KFB 345 & C. lanatus, (Farao) & Fruit & Ašanja & 2014 \\
\hline KFB 346 & C. lanatus, (Farao) & Fruit & Ašanja & 2014 \\
\hline KFB 347 & C. lanatus, (Farao) & Fruit & Ašanja & 2014 \\
\hline KFB 348 & C. lanatus, (Farao) & Fruit & Ašanja & 2014 \\
\hline KFB 349 & C. lanatus, (Farao) & Fruit & Ašanja & 2014 \\
\hline KFB 350 & C. lanatus, (Farao) & Fruit & Ašanja & 2014 \\
\hline KFB 351 & C. lanatus, (Unknow) & Fruit & Čelarevo & 2014 \\
\hline KFB 352 & C. lanatus, (Unknow) & Fruit & Čelarevo & 2014 \\
\hline KFB 365 & C. lanatus, (Top Gun) & Fruit & Rečka & 2015 \\
\hline KFB 366 & C. lanatus, (Top Gun) & Fruit & Rečka & 2015 \\
\hline KFB 367 & C. lanatus, (Top Gun) & Fruit & Rečka & 2015 \\
\hline KFB 368 & C. lanatus, (Top Gun) & Fruit & Rečka & 2015 \\
\hline KFB 369 & C. lanatus, (Eleta) & Fruit & Šabac & 2016 \\
\hline KFB 370 & C. lanatus, (Eleta) & Fruit & Šabac & 2016 \\
\hline KFB 371 & C. lanatus, (Eleta) & Fruit & Šabac & 2016 \\
\hline KFB 372 & C. lanatus, (Eleta) & Fruit & Šabac & 2016 \\
\hline $\mathrm{KBI}^{\mathrm{b}} 76$ & C. lanatus, (Farao) & Fruit & Ašanja & 2014 \\
\hline KBI 77 & C. lanatus, (Farao) & Fruit & Ašanja & 2014 \\
\hline KBI 78 & C. lanatus, (Farao) & Fruit & Ašanja & 2014 \\
\hline KBI 79 & C. lanatus, (Farao) & Fruit & Ašanja & 2014 \\
\hline KBI 80 & C. lanatus, (Farao) & Fruit & Ašanja & 2014 \\
\hline KBI 81 & C. lanatus, (Farao) & Fruit & Ašanja & 2014 \\
\hline KBI 82 & C. lanatus, (Farao) & Fruit & Ašanja & 2014 \\
\hline KBI 83 & C. lanatus, (Farao) & Fruit & Ašanja & 2014 \\
\hline KBI 84 & C. lanatus, (Farao) & Fruit & Ašanja & 2014 \\
\hline KBI 85 & C. lanatus, (Farao) & Fruit & Ašanja & 2014 \\
\hline KBI 86 & C. lanatus, (Farao) & Fruit & Ašanja & 2014 \\
\hline KBI 340 & C. lanatus, (Unknow) & Fruit & Leskovac & 2018 \\
\hline KBI 341 & C. lanatus, (Unknow) & Fruit & Leskovac & 2018 \\
\hline KBI 342 & C. lanatus, (Unknow) & Leaf & Leskovac & 2018 \\
\hline KBI 343 & C. lanatus, (Unknow) & Fruit & Šabac & 2018 \\
\hline KBI 344 & C. lanatus, (Unknow) & Fruit & Šabac & 2018 \\
\hline KBI 345 & C. lanatus, (Unknow) & Fruit & Šabac & 2018 \\
\hline KBI 346 & C. lanatus, (Unknow) & Fruit & Šabac & 2018 \\
\hline KBI 347 & C. lanatus, (Unknow) & Fruit & Šabac & 2018 \\
\hline KBI 348 & C. lanatus, (Unknow) & Fruit & Šabac & 2018 \\
\hline KBI 349 & C. lanatus, (Unknow) & Fruit & Šabac & 2018 \\
\hline KBI 350 & C. lanatus, (Unknow) & Fruit & Šabac & 2018 \\
\hline
\end{tabular}

${ }^{a}$ KFB Collection of Phytopathogenic Bacteria, University of Belgrade, Faculty of Agriculture, Serbia; ${ }^{\mathrm{b}}$ KBI Collection of Bacteria, Institute for Plant Protection and Environment, Belgrade, Serbia.

\subsection{Phenotypic Characterization}

The following differential physiological and biochemical tests were performed: Gram reaction using 3\% $\mathrm{KOH}$, catalase activity, fluorescence on King's medium $\mathrm{B}(\mathrm{KB})$ [25], growth on yeast extract-dextrose- $-\mathrm{CaCO}_{3}$ (YDC) agar and temperature tolerance at $41^{\circ} \mathrm{C}$, production of acid from L-arabinose, sucrose and sorbitol, nitrate reduction and oxidativefermentative $(\mathrm{O} / \mathrm{F})$ test $[26,27]$. In addition, levan production, oxidase activity, pectolytic activity on potato slices, arginine utilization and production of a hypersensitive reaction (HR) on tobacco (Nicotiana tabacum cv. 'Samsun') (LOPAT) were tested [28]. Strain 
A. citrulli NCPPB $3679^{\mathrm{T}}$ (National Collection of Plant Pathogenic Bacteria, strain isolated from C. lanatus in the USA) was used as positive control in all tests.

\subsection{Genomic DNA Extraction and PCR Identification}

Total genomic DNA was extracted according to the protocol described by Aljanabi and Martinez [29], with modifications. The following steps were added: (a) the samples were incubated at $37^{\circ} \mathrm{C}$ for 30 min after adding Proteinase K; (b) $1 \mu \mathrm{L}$ of RNase $(10 \mathrm{mg} / \mathrm{mL})$ was added to each sample before incubation; (c) incubation at $37^{\circ} \mathrm{C}$ for $1 \mathrm{~h}$. Quality of extracted DNA was checked by gel electrophoresis on $0.8 \%$ agarose gel and then stored at $-20^{\circ} \mathrm{C}$ for further analysis. PCR was performed by using A. citrulli-specific primers BX-L1/BX-S-R2 following the reaction conditions described by Bahar et al. [30] in order to amplify $279 \mathrm{bp}$ DNA fragment. The PCR program parameters consisted of initial denaturation at $95^{\circ} \mathrm{C}$ for $1 \mathrm{~min}$, followed by 35 cycles of $35 \mathrm{~s}$ at $94{ }^{\circ} \mathrm{C}, 35 \mathrm{~s}$ at $68.1^{\circ} \mathrm{C}$ and $45 \mathrm{~s}$ at $72{ }^{\circ} \mathrm{C}$ and a final extension for $7 \mathrm{~min}$ at $72{ }^{\circ} \mathrm{C}$. PCR reactions were performed in a Thermal Cycler 2720 (Applied Biosystem, Foster City, CA, USA). Amplified PCR products ( $5 \mu \mathrm{L}$ ) were separated by gel electrophoresis in $1.5 \%$ agarose gel in $1 \times$ Tris-acetate-EDTA (TAE) buffer, stained in ethidium bromide $(1 \mu \mathrm{g} / \mathrm{mL})$ and visualized under UV illuminator (Vilber Lourmat, Marne-la-Vallèe, France).

\section{4. $16 S$ rRNA Sequence Analysis}

The $16 \mathrm{~S}$ rRNA gene fragment was amplified and sequenced (Macrogene Europe, The Netherlands) for two selected strains (KFB 343 and KFB 344) using universal pair of primers fD1 and rP2 [31]. Chromatograms were analyzed using Finch TV 1.4.0 software, while sequences were processed using the MEGA 7 package [32]. BLAST program [33] was used for comparative analysis of the obtained sequences with the sequences deposited in the NCBI database. Partial sequences generated in this study were deposited in the GenBank database under accession numbers KP410333 and KP410334.

\subsection{Pathogenicity Test}

Pathogenicity of the strains was tested by spraying three two-week-old watermelon (cv. 'Rosa') seedlings per strain using hand-held sprayer. Bacterial suspensions were prepared from $24 \mathrm{~h}$ old cultures grown on NA and adjusted to $10^{8} \mathrm{CFU} / \mathrm{mL}$. The plants were sprayed until run-off in three replicates and were maintained in a greenhouse at approx. $27^{\circ} \mathrm{C}$, under plastic bags for $24 \mathrm{~h}$, in order to maintain high humidity. After that, plants were grown at approx. $27^{\circ} \mathrm{C}$ for two weeks. Sterile distilled water and A. citrulli NCPPB $3679^{\mathrm{T}}$ were used as negative and positive control, respectively.

\subsection{Host Preference}

In order to determine the host spectrum, we also performed the spray-inoculation tests as described above on seedlings of other cucurbit species, including cucumber (Cucumis sativus, cv. 'Sunčani potok'), melon (Cucumis melo, cv. 'Sezam'), pumpkin (Cucurbita pepo, cv. 'Beogradska') and butternut squash (Cucurbita moschata, cv. 'Nektar'). The experiment was performed in three replicates.

\subsection{Watermelon Cultivar's Susceptibility to A. citrulli}

Susceptibility of different watermelon cultivars to A. citrulli was tested by inoculating seedlings of six the most commonly grown cvs. in Serbia: Rosa, Crimson Sweet, Top Gun, Talisman, Bonta and Delta. Inoculation was performed by the spraying method as described in previous tests. SDW was used as negative, and A. citrulli NCPPB $3679^{\mathrm{T}}$ as positive control. This experiment was performed in three replicates.

\subsection{Strains Sensitivity to Bactericides}

The in vitro effect of different concentrations of copper (II) hydroxide, copper oxychloride and streptomycin sulfate on development and growth of A. citrulli strains isolated 
in Serbia was studied. Bacterial strains were grown on NA for $24 \mathrm{~h}$ and afterwards were suspended in SDW in concentration of approx. $1 \times 10^{8} \mathrm{CFU} / \mathrm{mL}$. Droplets $(3 \mu \mathrm{L})$ of each tested strain were spotted on the surface of sucrose peptone agar (SPA) plates [26] amended with either 100 or 200 ppm of copper hydroxide or copper oxychloride, and with 25 or 50 ppm of streptomycin sulfate, respectively [26]. Resistant Xanthomonas euvesicatoria E-3 (University of Florida, Gainesville, FL, USA) strain was used as a positive control. Strains able to grow on the tested medium were considered copper or streptomycin resistant. The experiment was repeated twice.

\subsection{Differentiation of Strains by Rep-PCR}

Genetic relatedness among the strains was assessed by rep-PCR fingerprinting. All 43 strains were amplified by BOXA1R primer [34]. PCR products were separated by gel electrophoresis on 1.5\% agarose gel in $1 \times$ TAE buffer. Amplified fragments were stained and visualized as described before.

\subsection{PCR Assays for Distinguishing Group I and II A. citrulli Strains}

PCR assay was performed as described by Zivanovic and Wallcott [19]. Reactions were conducted using two forward primers: G2AcFwd, specific for group II, and G12AcFwd, primer specific for both $A$. citrulli groups. Reverse primer G12AcRev was unique and used with both forward primers. Expected size of the amplified products was 291 and 254 bp, respectively.

In addition, duplex PCR assay proposed by Zhao et al. [21] was also applied for distinguishing groups I or II. Group I specific primer set 550-34F/550-626R and group II specific primers 2708-225F/2708-433R amplify $593 \mathrm{bp}$ and 209 bp products, respectively.

\subsection{Multilocus Sequence Analysis (MLSA)}

Based on results of previous tests, localities and year of isolation, 12 strains were selected for MLSA analysis. MLSA was conducted by PCR amplification and partial sequencing of 7 genes in total, including four housekeeping genes $(a d k, g y r B$, pilT and gltA), and three virulence-associated genes (Aave_1548, avrRx01 and $\operatorname{luxR}$ ), according to the protocol of Silva et al. [24]. Raw gene sequences obtained from Macrogen Europe (The Netherlands) were processed and deposited as described above for 16S rRNA gene sequences. The BLAST program described by Altschul et al. [33] was used to compare sequences obtained with those available in NCBI GenBank. CLUSTAL W algorithm [35] integrated into MEGA 7 software [32] was used for sequence alignments. The phylogenetic analysis was performed with IQ-TREE 1.6.12 [36] software available through the IQ-TREE web server (http:/ /iqtree.cibiv.univie.ac.at) (accessed on 10 September 2021) [37]. The bestfit DNA substitution model was selected based on Bayesian Information Criterion (BIC) [38]. Nine maximum likelihood trees in total were generated, seven for each gene and two for concatenated dataset of virulence and housekeeping genes. Branch support was assessed by ultrafast bootstrap analysis (UFBoot) using 1000 replicates [39]. The maximum likelihood trees were visualized using FigTree, v1.4.4 (http://tree.bio.ed.ac.uk/software/figtree/) (accessed on 10 September 2021) [40]. Generated partial sequences were deposited in the NCBI GenBank database under accession numbers MZ148272 and MZ501872-501931.

\section{Results}

\subsection{Isolation and Phenotypic Characterization of Bacterial Strains}

From the samples collected in five localities, 43 Acidovorax-like strains were isolated (Table 1). Forty-two strains were isolated from mature watermelon fruits, while one was recovered from watermelon leaf. The strains formed circular, glistening, slightly convex, whitish colonies with regular edge on NA after 24-48 h. All strains were Gram-negative, oxidase and catalase positive and nonfluorescent. They grew at $41^{\circ} \mathrm{C}$ and produced beige to tan-colored, round, nonmucoid and convex colonies on YDC agar. All strains utilized L-arabinose, were arginine dihydrolase and levan negative, did not reduce nitrate, nor 
utilize sucrose and sorbitol. They produced a weak oxidative reaction in $\mathrm{O} / \mathrm{F}$ test and did not induce potato soft rot. All but two, KBI 82 and KBI 86, induced hypersensitive reaction in tobacco leaves (Table 2). According to the results, the strains isolated from watermelon in Serbia belong to $A$. citrulli [27]. In addition, we observed loss of vitality in one month when the strains were stored as a suspension in SDW at $4{ }^{\circ} \mathrm{C}$, respectively [41].

Table 2. Bacteriological characteristics of strains isolated from watermelon plants in Serbia.

\begin{tabular}{|c|c|c|c|}
\hline \multirow{3}{*}{ Test } & \multicolumn{3}{|c|}{ Results $^{\text {a }}$} \\
\hline & \multicolumn{2}{|l|}{ Investigated Strains $\mathbf{b}$} & \multirow{2}{*}{$\begin{array}{l}\text { Control Strain }^{\mathrm{c}} \\
\text { NCPPB } 3679^{\mathrm{T}}\end{array}$} \\
\hline & $\begin{array}{c}\text { KFB } 340-352, \text { KFB 365-372, } \\
\text { KBI 76-81, KBI 83-85, KBI } \\
340-350\end{array}$ & $\begin{array}{l}\text { KBI 82, } \\
\text { KBI } 86\end{array}$ & \\
\hline Gram reaction & - & - & - \\
\hline Catalase activity & + & + & + \\
\hline Growth on $41^{\circ} \mathrm{C}$ & + & + & + \\
\hline Fluorescens on Kings medium B & - & - & - \\
\hline Levan production & - & - & - \\
\hline Oxidase production & + & + & + \\
\hline Pectinolytic activity & - & - & - \\
\hline Arginine dihydrolase production & - & - & - \\
\hline Tobacco hypersensitivity & + & - & + \\
\hline Oxidative-fermentative $(\mathrm{O} / \mathrm{F})$ test & $(\mathrm{O})$ & $(\mathrm{O})$ & $(\mathrm{O})$ \\
\hline Nitrate reduction & - & - & - \\
\hline \multicolumn{4}{|l|}{ Acid production from: } \\
\hline Arabinose & + & + & + \\
\hline Sucrose & - & - & - \\
\hline Sorbitol & - & - & - \\
\hline
\end{tabular}

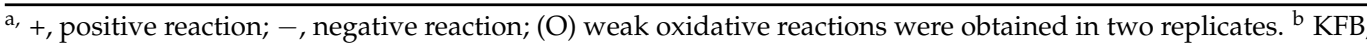
Collection of Phytopathogenic Bacteria, University of Belgrade, Faculty of Agriculture, Serbia; KBI Collection of Bacteria, Institute for Plant Protection and Environment, Belgrade, Serbia. ${ }^{c}$ NCPPB, National Collection of Plant Pathogenic Bacteria, Central Science Laboratory, York, United Kingdom.

\subsection{PCR Identification and $16 S$ rRNA Sequence Analysis}

PCR reaction with BX-L1/BX-S-R2 primers yielded 279 bp DNA fragment in all tested strains, indicating their affiliation to $A$. citrulli species (Figure 1). The 16S rRNA gene sequence from two strains (GenBank Accession Nos. KP410333 and KP410334) showed $100 \%$ identity to A. citrulli strains from China (KJ210353), Thailand (KJ210352) and USA (KJ210339), previously deposited in the NCBI GenBank database. Phylogenetic tree revealed that strains KFB 343 and KFB 344 grouped with A. citrulli, A. cattleyae and A. avenae strains (data not shown).

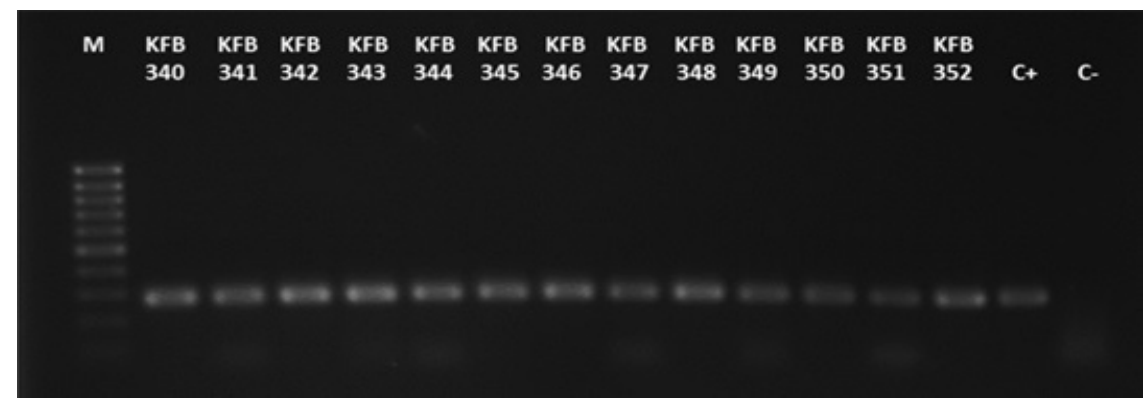

Figure 1. Conventional PCR with BX-L1/BX-S-R2 primer set specific for A. citrulli. Strain designations are indicated above the respective lines. Lane $\mathrm{M}$, molecular size marker GeneRuler 100 bp DNA Ladder (Thermo Scientific ${ }^{\mathrm{TM}}$ SM0241, Göteborg, Sweden), line C+ is positive control NCPPB $3679^{\mathrm{T}}$, line $\mathrm{C}$ - is negative control. 


\subsection{Pathogenicity Test and Host Preference}

All tested strains except two, KBI 82 and KBI 86, caused characteristic symptoms on inoculated watermelon seedlings. Water-soaked lesions developed on the abaxial side of cotyledons two days after inoculation while symptoms on the adaxial side appeared three days later (Supplementary Figure S1). Necrosis and seedling dieback occurred within 7 days. Plants inoculated with SDW as well with strains KBI 82 and KBI 86 did not develop symptoms. Bacteria were reisolated from the inoculated plants and identified as A. citrulli by the PCR [6]. In pathogenicity tests on several other cucurbit hosts, cucumber, melon, pumpkin and butternut squash, all tested strains, except KBI 82 and KBI 86, produced symptoms resembling those on watermelon seedlings, such as irregularly shaped watersoaked lesions. Identity of reisolated bacteria was confirmed by the PCR. No symptoms were observed on tissue inoculated with SDW.

\subsection{Cultivars Susceptibility to A. citrulli}

In this study, we tested the susceptibility of six commonly grown watermelon cvs.: Rosa, Crimson Sweet, Top Gun, Talisman, Bonta and Delta. The results showed that all the tested watermelon cvs. were sensitive to A. citrulli. No significant difference in the symptom development was observed. Characteristic water-soaked lesions were detected on all tested plants two days after inoculation.

\subsection{Susceptibility to Bactericides}

Copper compounds inhibited growth of all tested strains except KFB 368. This strain grew on SPA plates amended with $100 \mathrm{ppm}$ of copper (II) hydroxide while at concentration of $200 \mathrm{ppm} \mathrm{Cu}(\mathrm{OH})_{2}$ a weak bacterial growth was observed. This strain is tolerant to $100 \mathrm{ppm}$ of copper oxychloride but two times higher concentration inhibited growth. The reaction of strains to streptomycin was variable as well. Seventeen strains were tolerant to the lower concentration of streptomycin sulfate, while five strains tolerated both 25 and $50 \mathrm{ppm}$ of the antibiotic (Supplementary Table S1).

\subsection{Differentiation of Strains by Rep-PCR}

The obtained genetic fingerprints showed that all tested strains, except KFB 358, belong to the same BOX-PCR group. The genetic profile of this strain had an extra fragment of approx. $3500 \mathrm{bp}$, when compared with the other profiles.

\subsection{Distinguishing Group I and II of A. citrulli Strains}

Conventional PCR, proposed by Zivanovic and Wallcott [19], yielded specific fragment with primer set G12AcFwd/G12AcRev. These primers amplify DNA region of $254 \mathrm{bp}$ in strains of both A. citrulli groups. Using the group II specific primers G2AcFwd/G12AcRev, an expected $291 \mathrm{bp}$ fragment was amplified in all tested strains. Based on obtained results, it is shown that all Serbian A. citrulli strains belong to the group II. Duplex PCR reaction by Zhao et al. [21] resulted in amplification of a $209 \mathrm{bp}$ fragment, which confirmed previous results.

\subsection{Multilocus Sequence Analysis (MLSA)}

Sequences of the four housekeeping genes (gyrB, pilT, adk, gltA) and three virulenceassociated genes (Aave_1548, avrRx01, luxR) were analyzed. Phylogenetic trees were generated based on obtained sequences for each gene, as well as on concatenated datasets of four housekeeping and three virulence genes (Figures 2 and 3). Partial sequences obtained were identical for all 12 tested strains isolated in Serbia, except for gene luxR, where strain KBI 342 exhibited one SNP. They clustered together with the reference strain belonging to group II of $A$. citrulli. However, strains isolated from different non-watermelon hosts in China, Brazil and Mexico were placed within the group I, together with group I model strain M6, isolated in Israel from melon (Supplementary Figures S2-S8). There 
was no significant difference in strains' distribution on phylogenetic trees generated from concatenated datasets and nucleotide sequences of single genes.

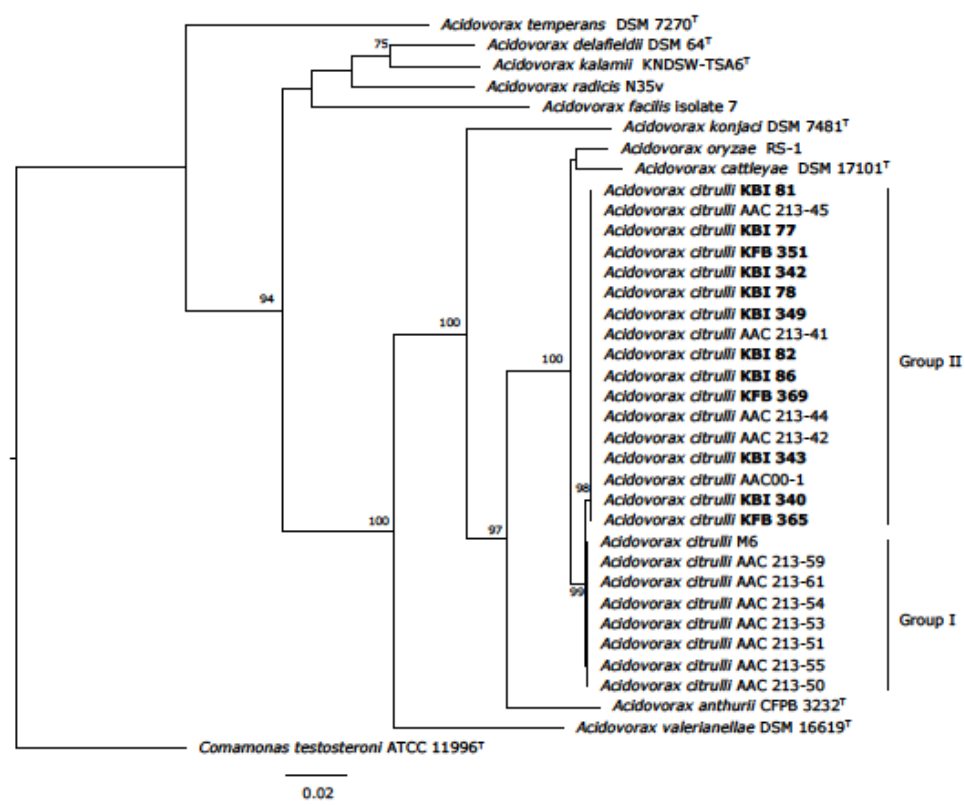

Figure 2. Maximum likelihood tree based on concatenated housekeeping genes $a d k$, pilT, gyrB and glt $A$ (2404 bp) sequences. The tree indicates the phylogenetic position of 12 representative $A$. citrulli strains (marked in bold). Comamonas testosteroni (strain ATCC $11996^{\mathrm{T}}$ ) was used as the outgroup organism. General time-reversible model with rate heterogeneity across Gamma model (GTR + G4 + F) was applied for tree construction. Ultrafast bootstrap support values $(>70)$ are indicated at the nodes. Classification of strains into group I and II is shown on the phylogenetic tree.

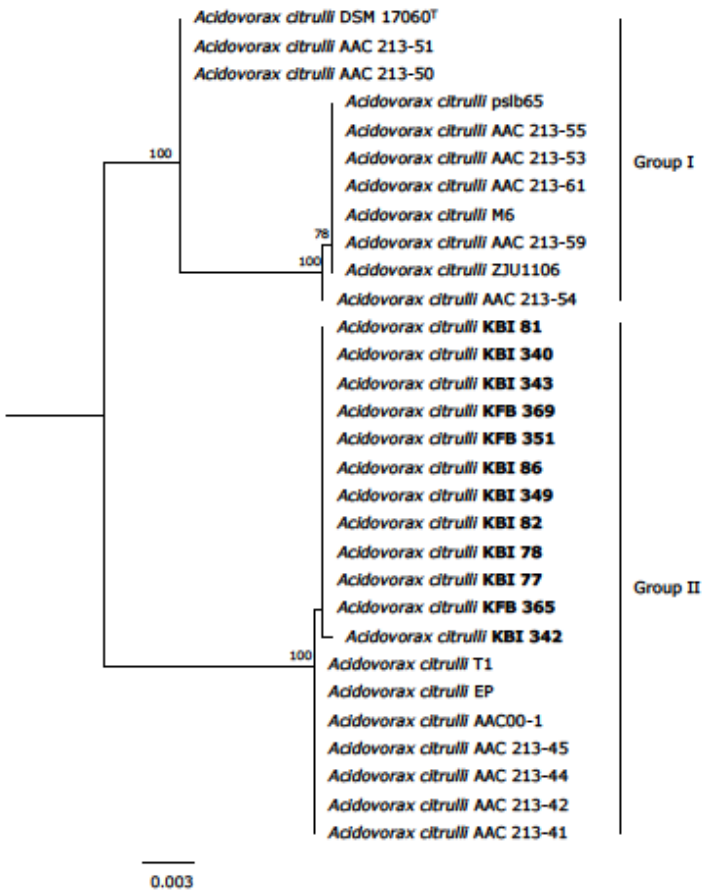

Figure 3. Maximum likelihood tree based on concatenated virulence genes Aave_1548, avrRx01 and luxR (1873 bp). Phylogenetic position of 12 representative strains isolated within this study is marked in bold. The tree was midpoint rooted. The scale bar represents the number of expected substitutions per site under the best-fitting HKY + F model. Branch support was assessed by ultrafast bootstrap analysis (UFBoot) using 1000 replicates. Classification of strains into group I and II is showed on the phylogenetic tree. 


\section{Discussion}

A. citrulli is a quarantine pathogen in Serbia and BFB outbreaks were recorded sporadically in different areas in the country starting from 2014. Thus, we studied 43 strains isolated from watermelon in 2014, 2015, 2016 and 2018. In all outbreaks, extent of the yield reduction was very high, reaching over $90 \%$. The objectives were to characterize and determine genetic relatedness among the $A$. citrulli strains isolated in Serbia and worldwide, to check the strains' pathogenicity and host range by inoculating various cucurbit species and different watermelon cultivars, and to study sensitivity of strains to different bactericides.

In 2014, when the first outbreak in Serbia was recorded, water-soaked, irregularly shaped lesions with slightly raised margins were noticed on watermelon fruits at the time of their physiological maturity. This was quickly followed by development of the fruit rind cracks and inner tissue softening [17,41]. It is possible that such lesions represented a pathway for penetration of other opportunistic microorganisms causing the fruit maceration and degradation.

Different molecular techniques were used to identify and characterize isolated strains. Aside from conventional PCR, the 16s rRNA analysis represents one of the essential tools for identification and determination of relationships between bacterial strains. Therefore, two representative strains, KFB 343 and KFB 344, were analyzed by partial sequencing of their $16 \mathrm{~S}$ rDNA. Comparing obtained sequences with those previously deposited in the NCBI GenBank, the causal organism of watermelon disease in Serbia was placed in genus Acidovorax. They showed $100 \%$ identity to A. citrulli strains, but also the tree revealed that investigated strains grouped to $A$. cattleyae and $A$. avenae (data not shown). Therefore, we further characterized investigated strains by using more discriminatory methods. Repetitive sequence-based polymerase chain reaction (rep-PCR) was applied to constitute a genomic fingerprint for tested strains. According to the BOX-PCR profiles, all the strains isolated in four seasons in Serbia belong to the highly homogeneous group. No significant differences were observed, with the exception of only one strain (KFB 358).

Based on biochemical and genetic characteristics, the A. citrulli population can be divided into groups I and II [8,12,15,19-21]. Eckshtain-Levi et al. [42] recognized even a third group which includes only two strains weakly virulent on watermelon, squash and melon seedlings [19]. For distinguishing in which group our strains belong, we applied conventional PCR described by Zivanovic and Walcott [19] and duplex PCR assay described by Zhao et al. [21]. The results placed our strains in group II. In order to investigate phylogenetic relationships of species within a genus, MLSA currently represents a widely-used method [23]. In our study, $12 \mathrm{~A}$. citrulli strains originating from Serbia were selected for MLSA analysis. The assay was performed by sequencing of four housekeeping genes and three virulence genes based on a scheme proposed by Silva et al. [24]. MLSA phylogenetic analysis was performed on individual gene sequences and on concatenated dataset. The obtained results showed all 12 tested strains belong to the same phylogenetic group. They lacked genetic diversity, only strain KFB 342 exhibited one SNP for gene luxR. Our strains clustered together, within one branch, together with the group II reference strain AAC00-1. According to virulence genes analysis, it is shown that strains EP and T1 isolated from eggplant and tomato in Israel are closely related to our and other group II strains (Supplementary Figures S2-S4). Phylogenetic trees also indicate that A. citrulli strains isolated from other cucurbits worldwide formed a separate group together with group I reference strain M6 (Figures 2 and 3, Supplementary Figures S2-S8).

Two strains, KBI 82 and KBI 86, did not induce hypersensitive response in tobacco leaves nor cause any symptoms in pathogenicity tests and on other cucurbit plants in cross inoculation test. Based on these properties, it is possible that strains KBI 82 and KBI 86 are lacking some of the virulence genes. The strains were isolated from two separate watermelon plants with BFB symptoms in the same field, indicating dissemination of the nonpathogenic population in the area. Nonpathogenic strains of $A$. citrulli were described previously; Schaad et al. [43] suggested that some A. citrulli strains do not produce a hypersensitive response in plants. Johnson et al. [44] indicated there are nonpathogenic 
A. citrulli strains. They can occur naturally or can be generated by mutagenesis. The loss of pathogenicity and the ability to induce HR in nonhost plants occurs as a consequence of mutation in T3SS genes [44]. Nevertheless, strains KBI 82 and KBI 86 exhibited biochemical and genetic features typical for $A$. citrulli.

It other studies, it was shown that group I and II strains vary in virulence on watermelon and non-watermelon plants $[8,12,15,19,22]$. Watermelon strains were highly virulent on watermelon, while weakly virulent on other species. In our study, cross inoculation tests indicated a wide host range of $A$. citrulli despite their group II designation and potential interference in agricultural production of other cucurbits. Some of the predominant watermelon varieties in Serbia, Rosa, Crimson Sweet, Top Gun, Talisman, Bonta and Delta, were tested for susceptibility to BFB. The trials showed there are no resistant cultivars, as suggested by other literature data $[7,45]$. Limited resistance has been found in a small number of plant introductions (PIs) in watermelon [46]. However, some genotypes at most stages of plant development showed high level of resistance, which suggests that they possess BFB resistance genes and could be used in breeding [45]. Recently, a group of researchers from South Korea developed a marker for distinguishing resistant and susceptible melon genotypes through a PCR assay [47].

Cultural measures often do not give appropriate results in bacterial diseases control. Furthermore, antibiotics are not allowed in Serbia for plant disease control [48]. Copper-based compounds are the most widely-used chemicals for managing BFB and other bacterial diseases in the field [49]. Hence, producers often resort to uncontrolled use of copper compounds, which can lead to the pathogen resistance. In tests of reaction to the bactericides within this study, the strains were more tolerant to streptomycin sulfate than to copper (II) hydroxide and copper oxychloride. Copper inhibited growth of all tested strains but one (KFB 368), thus treatment based on this compound could potentially improve control efficacy of BFB. Twenty-eight strains out of forty-three were sensitive to the lower concentration of streptomycin sulfate, while five strains grew even on the media amended with 50 ppm of this antibiotic. These results suggest the possibility of resistance development. Considering the negative effects of chemical measures, their insufficient efficiency in control of bacterial diseases as well as their negative impact to the environment, development of BFB resistant cultivars will have substantial role in the disease control.

Being that the pathogen is seed-borne, it can be easily introduced in the countries where its presence is not determined yet. Indeed, trade of infected seed lots and seedlings has the most important role in spreading the disease all over the world. Despite efforts to prevent the spread of disease in Serbia by phytosanitary control measures, the pathogen was detected in watermelon fields. According to the producers, symptoms similar to BFB were noticed even earlier, but the disease was unknown and probably misdiagnosed. Since there are no adequate chemical measures, this kind of control is indispensable. Seeds from symptomatic and asymptomatic fruits of the same watermelon genotypes showed transmission rates of $A$. citrulli up to $35.3 \%$. These results confirm that asymptomatic fruits can harbor contaminated seeds which lead to the transmission of the pathogen [45]. Probably the most efficient strategy for BFB control would be to eliminate the pathogen from seed, fruit, and transplant production systems [44]. It would be convenient to produce cucurbit seeds in regions with cooler and dry climates where BFB development would be limited [50]. It is necessary to apply control measures such as using certified seed, inspection of transplants, destruction of all symptomatic plants, sanitation procedures, elimination of plant debris and crop rotation. Chemical compounds could prevent infection emergence, but pathogen localization often interferes with efficacy of treatment. Implementation of resistant cultivars is an important step in future BFB management, but it is difficult to execute. Breeding programs are usually time consuming, expensive, very complex and diverse. In addition, timely and reliable diagnosis has a decisive role in crop protection. It is crucial to improve our knowledge about $A$. citrulli pathogenesis. By gathering all obtained facts, it will be possible to enhance strategies in order to reduce the economic impact of BFB worldwide. 
Supplementary Materials: The following are available online at https:/ / www.mdpi.com/article/ 10.3390/agronomy12020235/s1, Figure S1: Water-soaked lesions development on watermelon cotyledon. Artificial inoculation. Photo: A. Obradović., Figure S2: Phylogenetic tree based on Aave_1548 sequence data. Position of 12 representative A. citrulli strains isolated within this study is marked in bold. The tree was midpoint rooted. The best fitting model F81 + F was applied for tree construction. Ultrafast bootstrap support values $(>70)$ are indicated at the nodes. Classification of strains into group I and II was showed on the phylogenetic tree. Figure S3: Phylogenetic tree based on avrRx01 sequence data. Position of 12 representative A. citrulli strains isolated within this study is marked in bold. The tree was midpoint rooted. The best fitting model HKY + F was applied for tree construction. Ultrafast bootstrap support values $(>70)$ are indicated at the nodes. Classification of strains into group I and II is shown on the phylogenetic tree. Figure S4: Phylogenetic tree based on luxR sequence data. Position of 12 representative A. citrulli strains isolated within this study is marked in bold. The tree was midpoint rooted. The best fitting model F81 + F was applied for tree construction. Ultrafast bootstrap support values $(>70)$ are indicated at the nodes. Classification of strains into group I and II is shown on the phylogenetic tree. Figure S5: Phylogenetic tree based on adk sequence data. Position of 12 representative $A$. citrulli strains isolated within this study is marked in bold. The tree was midpoint rooted. The best fitting model TIM + G4 + F was applied for tree construction. Ultrafast bootstrap support values $(>70)$ are indicated at the nodes. Classification of strains into group I and II is shown on the phylogenetic tree. Figure S6: Phylogenetic tree based on gltA sequence data. Position of 12 representative $A$. citrulli strains isolated within this study is marked in bold. The tree was midpoint rooted. The best fitting model TIM + G4 + F was applied for tree construction. Ultrafast bootstrap support values $(>70)$ are indicated at the nodes. Classification of strains into group I and II is shown on the phylogenetic tree. Figure S7: Phylogenetic tree based on gyrB sequence data. Position of 12 representative $A$. citrulli strains isolated within this study is marked in bold. The tree was midpoint rooted. The best fitting model TVM + G4 + F was applied for tree construction. Ultrafast bootstrap support values $(>70)$ are indicated at the nodes. Classification of strains into group I and II is shown on the phylogenetic tree. Figure S8: Phylogenetic tree based on pilT sequence data. Position of 12 representative $A$. citrulli strains isolated within this study is marked in bold. The tree was midpoint rooted. The best fitting model GTR + G4 + F was applied for tree construction. Ultrafast bootstrap support values $(>70)$ are indicated at the nodes. Classification of strains into group I and II are shown on the phylogenetic tree. Table S1: Susceptibility of isolated strains to bactericides.

Author Contributions: Conceived and designed the experiments: N.Z., K.G. and A.O. Performed the experiments: N.Z., K.G., N.K., A.P., M.I. and S.Ž. Analyzed the data: N.Z., N.K. and K.G. Wrote the paper: N.Z., K.G. and N.K. Revised the paper: A.O. All authors have read and agreed to the published version of the manuscript.

Funding: N.Z., K.G., AP., M.I., S.Ž. and A.O. were supported by the Ministry of Education, Science and Technological Development, Republic of Serbia, Contract Nos. 451-03-9/2021-14/200010 (N.Z., K.G., S.Ž.); 451-03-9/2021-14/200116 (A.P., M.I., A.O.). The work of N.K. was funded by the Deutsche Forschungsgemeinschaft (DFG, German Research Foundation)—Project Number 429677233.

Data Availability Statement: The sequences presented in this study are deposited in NCBI GenBank database. Accession numbers of housekeeping genes sequences (Nos. MZ148272, MZ501872-501931) are shown in parentheses on phylogenetic trees, while sequences for 16S rRNA are stated in Section 2.4. (Nos. KP410333 and KP410334) and can be found in the NCBI bank.

Conflicts of Interest: The authors declare that the research was conducted in the absence of any commercial or financial relationships that could be construed as a potential conflict of interest.

\section{References}

1. FAOSTAT. Food and Agriculture Organization of the United Nations. Available online: www.fao.ogr/faostat (accessed on 25 September 2021).

2. Webb, R.; Goth, R. A seedborne bacterium isolated from watermelon. Plant Dis. Rep. 1965, 49, 818-821.

3. Schaad, N.W.; Sowell, G.; Goth, R.W.; Colwell, R.R.; Webb, R.E. Pseudomonas pseudoalcaligenes subsp. citrulli subsp. nov. Int. J. Syst. Evol. Microbiol. 1978, 28, 117-125. [CrossRef]

4. $\quad$ Feng, J.J.; Li, J.Q.; Walcott, R.R.; Zhang, G.M.; Luo, L.X.; Kang, L.; Zheng, Y.; Schaad, N.W. Advances in detection of Acidovorax citrulli, the causal agent of bacterial fruit blotch of cucurbits. Seed Sci. Technol. 2013, 41, 1-15. [CrossRef] 
5. Schaad, N.W.; Postnikova, E.; Sechler, A.; Claflin, L.E.; Vidaver, A.K.; Jones, J.B.; Agarkova, I.; Ignatov, A.; Dickstein, E.; Ramundo, B.A. Reclassification of subspecies of Acidovorax avenae as A. avenae (Manns 1905) emend., A. cattleyae (Pavarino 1911) comb. nov., A. citrulli (Schaad et al., 1978) comb. nov., and proposal of A. oryzae sp. nov. Syst. Appl. Microbiol. 2008, 31, 434-446. [CrossRef]

6. Bahar, O.; Burdman, S. Bacterial fruit blotch: A threat to the cucurbit industry. Isr. J. Plant Sci. 2010, 58, 19-31. [CrossRef]

7. Burdman, S.; Walcott, R. Acidovorax citrulli: Generating basic and applied knowledge to tackle a global threat to the cucurbit industry. Mol. Plant Pathol. 2012, 13, 805-815. [CrossRef]

8. Feng, J.; Schuenzel, E.L.; Li, J.; Schaad, N.W. Multilocus sequence typing reveals two evolutionary lineages of Acidovorax avenae subsp. citrulli. Phytopathology 2009, 99, 913-920. [CrossRef]

9. Mirik, M.; Aysan, Y.; Sahin, Y. Occurrence of bacterial fruit blotch of watermelon caused by Acidvorax avenae subsp. citrulli in the eastern Mediterranean region of Turkey. Plant Dis. 2006, 90, 829. [CrossRef]

10. Palkovics, L.; Petróczy, M.; Kertész, B.; Németh, J.; Bársony, C.; Mike, Z.; Hevesi, M. First Report of Bacterial Fruit Blotch of Watermelon Caused by Acidovorax avenae subsp. citrulli in Hungary. Plant Dis. 2008, 92, 834. [CrossRef]

11. Holeva, M.C.; Karafla, C.D.; Glynos, P.E.; Alivizatos, A.S. Acidovorax avenae subsp. citrulli newly reported to cause bacterial fruit blotch of watermelon in Greece. Plant Pathol. 2010, 59, 797. [CrossRef]

12. Walcott, R.R.; Fessehaie, A.; Castro, A.C. Differences in Pathogenicity between two Genetically Distinct Groups of Acidovorax avenae subsp. citrulli on Cucurbit Hosts. J. Phytopathol. 2004, 152, 277-285. [CrossRef]

13. Zhao, M.; Walcott, R. Acidovorax citrulli: History, Epidemiology, and Management of Bacterial Fruit Blotch of Cucurbits. In Plant Pathogenic Acidovorax Species; Burdman, S., Walcott, R., Eds.; APS Press: Saint Paul, MN, USA, 2018; pp. 39-57. [CrossRef]

14. Assouline, I.; Milshtein, H.; Mizrachi, M.; Levy, E.; Ben-Ze'ev, I.S. Acidovorax avenae subsp. citrulli transmitted by Solanaceous seeds. Phytoparasitica 1997, 25, 2. [CrossRef]

15. Burdman, S.; Kots, N.; Kritzman, G.; Kopelowitz, J. Molecular, physiological, and host-range characterization of Acidovorax avenae subsp. citrulli isolates from watermelon and melon in Israel. Plant Dis. 2005, 89, 1339-1347. [CrossRef] [PubMed]

16. Chalupowicz, L.; Reuven, M.; Dror, O.; Sela, N.; Burdman, S.; Manulis-Sasson, S. Characterization of Acidovorax citrulli strains isolated from solanaceous plants. Plant Pathol. 2020, 69, 1787-1797. [CrossRef]

17. Malliarakis, D.; Mpalantinaki, E.; Pagoulatou, M.G.; Lorenzou, K.; Goumas, D. First report of Acidovorax citrulli causing a leaf spot disease on tomato plants in Greece. J. Plant Pathol. 2021, 103, 353. [CrossRef]

18. Popović, T.; Ivanović, Ž. Occurrence of Acidovorax citrulli Causing Bacterial Fruit Blotch of Watermelon in Serbia. Plant Dis. 2015, 99, 886. [CrossRef]

19. Zivanovic, M.; Walcott, R. Further characterization of genetically distinct groups of Acidovorax citrulli strains. Phytopathology 2017, 107, 29-35. [CrossRef] [PubMed]

20. Walcott, R.R.; Langston, D.B.; Sanders, F.H.; Gitaitis, R.D. Investigating Intraspecific Variation of Acidovorax avenae subsp. citrulli Using DNA Fingerprinting and Whole Cell Fatty Acid Analysis. Phytopathology 2000, 90, 191-196. [CrossRef]

21. Zhao, M.; Dutta, B.; Luo, X.; Burdman, S.; Walcott, R. Genetically Distinct Acidovorax citrulli Strains Display Cucurbit Fruit Preference under Field Conditions. Phytopathology 2020, 110, 973-980. [CrossRef]

22. O'Brien, R.G.; Martin, H.L. Bacterial blotch of melons caused by strains of Acidovorax avenae subsp. citrulli. Aust. J. Exp. Agric. 1999, 39, 479-485. [CrossRef]

23. Glaeser, S.P.; Kämpfer, P. Multilocus sequence analysis (MLSA) in prokaryotic taxonomy. Syst. Appl. Microbiol. 2015, 38, 237-245. [CrossRef]

24. Silva, G.M.; Souza, R.M.; Yan, L.; Junior, R.S.; Medeiros, F.H.; Walcott, R.R. Strains of the group I lineage of Acidovorax citrulli, the causal agent of bacterial fruit blotch of cucurbitaceous crops, are predominant in Brazil. Phytopathology 2016, 106, 1486-1494. [CrossRef]

25. King, E.O.; Ward, M.; Raney, D.E. Two simple media for the demonstration of pyocyanin and fluorescein. J. Lab. Clin. Med. 1954, 44, 301-307.

26. Lelliott, R.A.; Stead, D.E. Methods for the diagnosis of bacterial diseases of plants. In Methods in Plant Pathology; Blackwell Scientific Publications: Oxford, UK, 1987; Volume 2.

27. Jones, J.B.; Gitaitis, R.D.; Schaad, N.W. Gram-negative bacteria: Acidovorax and Xylophilus. In Laboratory Guide for Identification of Plant Pathogenic Bacteria, 3rd ed.; Schaad, N.W., Jones, J.B., Chen, W., Eds.; APS Press: Saint Paul, MN, USA, 2001 ; pp. $121-138$.

28. Lelliott, R.A.; Billing, E.; Hayward, A.C. A determinative scheme for the fluorescent plant pathogenic pseudomonads. J. Appl. Microbiol. 1966, 29, 470-489. [CrossRef] [PubMed]

29. Aljanabi, S.M.; Martinez, I. Universal and rapid salt-extraction of high quality genomic DNA for PCR-based techniques. Nucleic Acids Res. 1997, 25, 4692-4693. [CrossRef] [PubMed]

30. Bahar, O.; Efrat, M.; Hadar, E.; Dutta, B.; Walcott, R.R.; Burdman, S. New subspecies-specific polymerase chain reaction-based assay for the detection of Acidovorax avenae subsp. citrulli. Plant Pathol. 2008, 57, 754-763. [CrossRef]

31. Weisburg, W.G.; Barns, S.M.; Pelletier, D.A.; Lane, D.J. 16 S ribosomal DNA amplification for phylogenetic study. J. Bacteriol. 1991, 173, 697-703. [CrossRef]

32. Kumar, S.; Stecher, G.; Tamura, K. MEGA7: Molecular Evolutionary Genetics Analysis version 7.0 for bigger datasets. Mol. Biol. Evol. 2016, 33, 1870-1874. [CrossRef]

33. Altschul, S.F.; Madden, T.L.; Schäffer, A.A.; Zhang, J.; Zhang, Z.; Miller, W.; Lipman, D.J. Gapped BLAST and PSI-BLAST: A new generation of protein database search programs. Nucleic Acids Res. 1997, 25, 3389-3402. [CrossRef] 
34. Versalovic, J.; Schneider, M.; De Bruijn, F.J.; Lupski, J.R. Genomic fingerprinting of bacteria using repetitive sequence-based polymerase chain reaction. Methods Mol. Cell Biol. 1994, 5, 25-40.

35. Higgins, D.G.; Thompson, J.D.; Gibson, T.J. Using CLUSTAL for multiple sequence alignments. Methods Enzymol. 1996, 266, 383-402. [PubMed]

36. Nguyen, L.T.; Schmidt, H.A.; Von Haeseler, A.; Minh, B.Q. IQ-TREE: A fast and effective stochastic algorithm for estimating maximum likelihood phylogenies. Mol. Biol. Evol. 2015, 32, 268-274. [CrossRef] [PubMed]

37. Trifinopoulos, J.; Nguyen, L.T.; Von Haeseler, A.; Minh, B.Q. W-IQ-TREE: A fast online phylogenetic tool for maximum likelihood analysis. Nucleic Acids Res. 2016, 44, W232-W235. [CrossRef] [PubMed]

38. Kalyaanamoorthy, S.; Minh, B.Q.; Wong, T.F.K.; Von Haeseler, A.; Jermiin, L.S. Model Finder: Fast model selection for accurate phylogenetic estimates. Nat. Methods 2017, 14, 587-589. [CrossRef]

39. Hoang, D.T.; Chernomor, O.; Von Haeseler, A.; Minh, B.Q.; Vinh, L.S. UFBoot2: Improving the ultrafast bootstrap approximation. Mol. Biol. Evol. 2018, 35, 518-522. [CrossRef]

40. Rambaut, A. Figtree v1.4.4. Available online: http://tree.bio.ed.ac.uk/software/figtree/ (accessed on 10 September 2021).

41. Zlatković, N.; Prokić, A.; Kuzmanović, N.; Gašić, K.; Šević, M.; Ivanović, M.; Obradović, A. Bakteriozna mrljavost plodova lubenice u Srbiji. Biljni Lekar 2015, 43, 265-272. (In English)

42. Eckshtain-Levi, N.; Munitz, T.; Živanović, M.; Traore, S.M.; Spröer, C.; Zhao, B.; Welbaum, G.; Walcott, R.; Sikorski, J.; Burdman, S. Comparative analysis of type III secreted effector genes reflects divergence of Acidovorax citrulli strains into three distinct lineages. Phytopathology 2014, 104, 1152-1162. [CrossRef]

43. Schaad, N.W.; Jones, J.B.; Lacy, G.H. Laboratory Guide for Identification of Plant Pathogenic Bacteria, 3rd ed.; Schaad, N.W., Jones, J.B., Chun, W., Eds.; APS Press: Saint Paul, MN, USA, 2001; p. 373.

44. Johnson, K.L.; Minsavage, G.V.; Le, T.; Jones, J.B.; Walcott, R.R. Efficacy of a Nonpathogenic Acidovorax citrulli Strain as a Biocontrol Seed Treatment for Bacterial Fruit Blotch of Cucurbits. Plant Dis. 2011, 95, 697-704. [CrossRef]

45. Carvalho, F.C.Q.; Santos, L.A.; Dias, R.C.S.; Mariano, R.L.R.; Souza, E.B. Selection of watermelon genotypes for resistance to bacterial fruit blotch. Euphytica 2013, 190, 169-180. [CrossRef]

46. Wechter, W.P.; Levi, A.; Ling, K.S.; Kousik, C.; Block, C.C. Identification of resistance to Acidovorax avenae subsp. citrulli among melon (Cucumis spp.) plant introductions. HortScience 2011, 46, 207-212. [CrossRef]

47. Islam, M.R.; Hossain, M.R.; Jesse, D.M.I.; Jung, H.J.; Kim, H.T.; Park, J.I.; Nou, I.S. Development of Molecular Marker Linked with Bacterial Fruit Blotch Resistance in Melon (Cucumis melo L.). Genes 2020, 11, 220. [CrossRef] [PubMed]

48. Šević, M.; Gašić, K.; Ignjatov, M.; Mijatović, M.; Prokić, A.; Obradović, A. Integration of biological and conventional treatments in control of pepper bacterial spot. Crop Prot. 2019, 119, 46-51. [CrossRef]

49. Kan, Y.; Jiang, N.; Xu, X.; Lyu, Q.; Gopalakrishnan, V.; Walcott, R.; Burdman, S.; Li, J.; Luo, L. Induction and Resuscitation of the Viable but Non-culturable (VBNC) State in Acidovorax citrulli, the Causal Agent of Bacterial Fruit Blotch of Cucurbitaceous Crops. Front. Microbiol. 2019, 10, 1081. [CrossRef] [PubMed]

50. Walcott, R.; Gitaitis, R.D.; Castro, A.C. Role of blossoms in watermelon seed Infestation by Acidovorax avenae subsp. citrulli. Phytopathology 2003, 93, 528-534. [CrossRef] [PubMed] 